\title{
Sociobiology
}

RESEARCH ARTICLE - TERMITES

\section{Litter Quality Affects Termite Sheeting Production and Water Infiltration in the Soil}

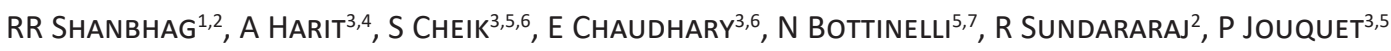 \\ 1 - Indian Plywood Industries Research and Training Institute, Bangalore, Karnataka, India \\ 2 - Institute of Wood Science and Technology, Bangalore, Karnataka, India \\ 3 - Indo-French Cell for Water Science (IFCWS), Civil Engineering Department, Indian Institute of Science, Bangalore, Karnataka, India \\ 4 - School of Environmental Sciences, Mahatma Gandhi University, Kottayam, Kerala, India \\ 5 - Institute of Ecology and Environmental Sciences (UMR 242 iEES Paris, UPMC, CNRS, IRD, INRA, UPEC, Univ. P. Diderot), Institute of \\ Research for Development, Bondy, France \\ 6 - Center for Ecological Sciences, Indian Institute of Science, Bangalore, Karnataka, India \\ 7 - Soils and Fertilizers Research Institute (SFRI), Hanoi, Vietnam
}

\section{Article History}

\section{Edited by}

Og DeSouza, UFV, Brazil

Received $\quad 16$ September 2018

Initial acceptance 21 December 2018

Final acceptance 23 March 2019

Publication date 14 November 2019

\section{Keywords}

Bait consumption, Odontotermes spp., India, Forest.

\section{Corresponding author \\ Pascal Jouquet \\ UMR iEES, FEST team \\ 32 av. H. Varagnat \\ 93143 Bondy, France \\ E-Mail: pascal.jouquet@ird.fr}

\begin{abstract}
This study aimed to understand the relationship between termite foraging activity and the ecological benefits derived from their activity in soil dynamics and water infiltration. A field study was carried out for six months, between pre-wet and wet seasons, with different food baits (elephant dung, Acacia auriculiformis leaves, twigs and leaves of Lantana camara as well as Ficus religiosa, Pterocarpus marsupium, Prosopis juliflora, Michelia champaca, Azadirachta indica and Hevea brasiliensis wood stakes) installed on the soil surface in a semi-deciduous forest in southern India. At the end of the experiment we determined bait consumption, water infiltration rate in soil, and the amount of soil sheetings covering the different baits. The initial infiltration rates under the baits were compared to those at the end of the experiment. Three termite species, Odontotermes obesus, $O$. feae and Microtermes obesi, were found associated with some of the baits in the study area. Among the different baits, elephant dung and Acacia leaves were the most preferred and a positive relationship was observed between the quantity of soil sheetings and the bait consumption rate. Termite preference for elephant dung and Acacia leaves was also associated with higher water infiltration rates. However, this difference was only significant at the beginning of the experiment and no significant difference was measured once the steady state was reached. In conclusion, we showed that resource quality was of primary importance for soil sheeting production but that the influence of termites on water infiltration remained limited, most likely because of the low stability of their tunnels in the soil.
\end{abstract}

\section{Introduction}

In terrestrial ecosystems, bioturbation by soil physical engineers (sensu Jones et al., 1994) regulate several important ecological processes, such as those influencing soil fertility and water dynamic in soil (Lavelle et al., 2006; Bottinelli et al., 2015). In temperate and tropical humid ecosystems this role is mainly carried out by earthworms (Lavelle et al., 1997). However, in tropical African and Asian drylands, termites, and especially fungus-growing termites (Macrotermitinae subfamily) are the key bioturbation agents (Jouquet et al., 2016). In these environments, they directly or indirectly influence the availability of nutrient and water resources to "subordinate organisms" (sensu Jouquet et al., 2006) from microorganisms to plants (e.g., Wood \& Sands, 1978; Schaefer \& Whitford, 1981; Konaté et al., 1999; Harry et al., 2001; Jouquet et al., 2005; Bignell, 2006; Sileshi et al., 2010). The influence of termites on ecosystem functioning relies on their ability to 
act as key decomposers of organic residues (Collins, 1981; Freyman et al., 2008, 2010; Fatondji et al., 2009) and in the formation of biostructures (termite mounds and sheetings) and biopores (tunnels and below-ground chambers) which have specific physical, chemical and biological properties differing from the surrounding soil environment (Holt \& Lepage, 2000; Jouquet et al., 2011).

Termite mounds are often conspicuous features of tropical landscapes and, for this reason, their specific properties and abundance have been extensively studied (e.g., Moe et al., 2009; Horiuchi et al., 2014; Joseph et al., 2014; Sujada et al., 2014; Jouquet et al., 2017; Shanbhag et al., 2017; Muvengwi et al., 2018). Comparatively, the specific properties and abundance of soil sheetings have received much less attention, although it has been suggested that they represent several tons of soil ha ${ }^{-1}$ year $^{-1}$ in some situations (Rouland et al., 2003; Ali et al., 2013; Harit et al., 2017a). Termites also influence soil functioning through the formation of foraging galleries which increase soil porosity (e.g., Lee \& Wood, 1971; Bottinelli et al., 2015) and consequently water infiltration (Elkins et al., 1986; Mando et al., 1996, 1999; Léonard \& Rajot, 2001; Mettrop et al., 2013) and water storage (Lobry \& Conacher, 1990; Ouédraogo et al., 2006; Pringle et al., 2010). As a consequence, this impact of termites on soil porosity and water dynamics makes them important agents of agro-ecosystem functioning (Mando \& Miedema, 1997; Evans et al., 2011; Jouquet et al., 2018).

Termites are considered "intended" or "extended soil engineers" since they manipulate soil functioning to protect themselves against desiccation and predators, to maintain a micro-climate within their constructions and/or to favor the growth of the vegetation they prefer to consume (Jouquet et al., 2006). The close relationship between the ecological impacts of termites and their ecological needs has mainly been demonstrated in the context of termite nest constructions (mounds and fungus-growing chambers) (Dangerfield et al., 1998; Jouquet et al., 2002, 2003; Turner, 2004). However, termites also adapt the amount and the properties of their sheetings depending on substrate physical and chemical properties and feeding preferences, with relatively long-lasting structures being most different to the parent soil material (Harit et al., 2017b). For example, non-fungus growing termites prefer mammalian dung over alternative food items because of its higher $\mathrm{C} / \mathrm{N}$ ratio (Freyman et al., 2008) and consequently use a larger amount of soil to cover dung pats than plant litter (Herrick \& Lal, 1996). As another example, a positive relationship was also measured in Senegal between the quantity of sheetings and the amount of substrate consumed by fungusgrowing termites as well as the number of pores on the surface (Rouland et al., 2003). Consequently, the relationship between food preference, bioturbation (i.e., the formation of sheeting and galleries) and water infiltration in soil remains unexplored, especially in Asia where the influence of fungus-growing termites on soil dynamic is poorly documented (Jouquet et al., 2016).
Therefore, the aim of this study was to examine the links between termite feeding preferences and the production of sheetings and galleries in a tropical forest in Southern India. We then investigated the relationship between resource quality, termite foraging activity and water infiltration in soil. Our hypotheses were that (i) the more termites prefer a type of resource and the more they produce sheetings above-ground and galleries below-ground, and (ii) that higher resource consumption is associated to greater water infiltration in soil.

\section{Materials and Methods}

\section{Study site and experimental design}

The study was carried out in a park at the Institute of Wood Science and Technology (IWST), Bangalore (13.0112 N, 77.5702 ${ }^{\circ}$ E) from February to August 2016. The study site is dominated by teak trees, which represent one of the major types of tree plantation in South India. The climate in the area is semi-arid with an average annual rainfall of 900 mm year ${ }^{-1}$, a mean annual temperature of $23.6^{\circ} \mathrm{C}$ and a wet (July-October), a dry (November-April) and pre-wet season (May-June) (Jouquet et al., 2015; Cheik et al., 2018). Situated at an elevation of 900 to $1000 \mathrm{~m}$ above sea level, the soil in the area is described as Luvisol by FAO (Soil Survey Staff, 2014). The soil is reddish brown in color and has a loamy texture with $\sim 19$ and $36 \%$ of clay and sand, respectively, and a bulk density of $\sim 0.9 \mathrm{~g} \mathrm{~cm}^{-3}$ and it is characterized by a good drainage (Soil Survey Staff, 2014). It is moderately acidic with low organic carbon content $(\sim 1.3 \%)$ (Cheik et al., 2018).

The experiment consisted in the utilization of organic baits that were placed on the soil surface to attract termites. Ten different substrates were used. Elephant dung ('ED') was chosen for its attractiveness because termites are often observed below elephant dung in South Indian forests (Chaudhary and Jouquet, com. pers.). Lantana camara twigs ('LT') and leaves ('LL') were also used because Lantana sp. is known to have secondary metabolites which act as feeding deterrents for termites (Sousa \& Costa, 2012). This plant is also an invasive species in India and how termites participate to its degradation remains unknown (Ramaswami \& Sukumar, 2014) and therefore an important question in this environment. Acacia auriculiformis leaves ('AC') and different wood stakes (Ficus religiosa ('FI'), Michelia champaca ('MI'), Hevea brasiliensis ('HB'), Prosopis juliflora ('PJ'), Pterocarpus marsupium ('PT') and Azadirachta indica ('AZ')) were also used because they constituted gradients of high quality resources, with higher $\mathrm{N}$ contents in leaves than in wood, and less to high density wood materials $(\mathrm{d} \sim 0.39,0.43,0.53,0.63,0.67$ and $0.93 \mathrm{~g} \mathrm{~cm}^{-3}$, respectively) (Shanbhag \& Sundararaj, 2013a,b). Recently produced ED ( $<2$ days), recently fallen and nondecayed AC collected on the ground and cut pieces of lantana (LT, $\sim 10 \mathrm{~cm}$ in length, and LL) were air-dried during 10 days before being placed on the soil surface while wood stakes (15 $\mathrm{cm}$ in length $\times 3.5 \times 3.5 \mathrm{~cm}$ ) were dried at $80^{\circ} \mathrm{C}$ during 2 days. 
All baits were weighed before the experiment ( $200 \mathrm{~g}$ bait ${ }^{1}$ in average). Since termite mounds were not visible in the study field, substrates were randomly distributed with a minimum distance between bait $\sim 2 \mathrm{~m}$. Baits were also covered by plastic boxes $(23 \mathrm{~cm}$ long $\times 17 \mathrm{~cm}$ wide $\times 8 \mathrm{~cm}$ height) performed with $2 \mathrm{~mm}$ holes on their sides. Boxes were covered on their top to protect them from the rain but they were open on the ground to allow soil fauna to have access to the baits. Five replicates were used per treatment and 5 boxes without baits were also installed on the soil surface for the control treatment.

\section{Biodiversity and litter consumption}

At the end of the experiment, all baits were carefully removed. Baits with termite activity were recorded. All active soil macrofauna under the baits but above the soil surface, including termites, were sampled and kept in vials containing $80 \%$ alcohol and further identified at the species or taxon level. Soil fauna diversity was described by the number of species and morpho-species (taxon richness, R) and the Shannon index (H').

Soil sheetings covering the substrates were collected and placed in separate plastic bags along with the residual organic bait. Both sheetings and bait materials, except wood samples, were dried at room temperature $\left(\sim 30^{\circ} \mathrm{C}\right)$ until they reached a constant weight, and then weighed and expressed as $\mathrm{g}$ soil sheeting $\mathrm{g}$ bait $^{-1}$. Wood stakes where dried at $80^{\circ} \mathrm{C}$ for two days. Termite feeding preferences were evaluated by comparing the weight of the baits before and after the experiment. Values were then converted to percentage weight loss. The amounts of soil translocated over the individual baits were also calculated.

\section{Soil physical properties}

Water infiltration rates were measured under the baits following the Beerkan method (Haverkamp et al., 1994; Braud et al., 2005). A cylinder (diam $11 \mathrm{~cm}$ ) was positioned at the soil surface and inserted to a depth of $1 \mathrm{~cm}$ to prevent lateral water loss. A fixed volume of water $(100 \mathrm{~mL}$, corresponding to a water depth of $1 \mathrm{~cm}$ ) was initially poured into the cylinder, and the time needed for the water to infiltrate was recorded. As soon as the first volume had completely infiltrated, another equal volume of water was added to the cylinder and the time for this volume to infiltrate (cumulative time) was recorded.
The procedure was repeated until steady state conditions were reached. A distinction was made between the infiltration rate at the beginning and end of the experiment. The first three recordings were considered as starting points and the average infiltration rate of the last three readings were considered for the last points. Undisturbed soil cores were also sampled in the surrounding top-soil environment $(0-5 \mathrm{~cm}$ depth) to confirm that initial water content, $\theta_{\mathrm{i}}\left(\mathrm{m}^{3} \mathrm{~m}^{-3}\right)$, was similar for all the treatments. The soil in the center of the cylinder was also sampled using a smaller cylinder ( 5.7 diam $\mathrm{x} 5 \mathrm{~cm}$ high). Samples were weighed humid and after drying at $110^{\circ} \mathrm{C}$ for 48 hours. These values were used to measure soil bulk density and gravimetric water content at saturation.

\section{Statistical analyses}

All statistics were calculated using $\mathrm{R}$ studio and $\mathrm{R}$ version 3.2.1. ( $\mathrm{R}$ development Core Team, 2008). Residues were tested for normality using the Shapiro-Wilk test and the homogeneity of variance was tested using Levene's test. A oneway analysis of variance (ANOVA) was performed on normally distributed data sets and differences between means were tested with Fischer least significant (LSD) tests. Data were analyzed using Kruskal-Wallis Chi-squared tests when residues failed to show normal distribution even after log-transformation. Differences were considered significant at $P<0.05$.

\section{Results}

\section{Soil biodiversity}

The influence of the feeding baits on soil macrofauna biodiversity is shown in Table 1. No significant difference in taxon richness and Shannon index could be measured (Kruskal-Wallis test, $\mathrm{p}=0.235$ and 0.388 for $\mathrm{R}$ and $\mathrm{H}^{\prime}$, respectively). Three termite species were found (Odontotermes obesus, O. feae and Microtermes obesi) in AC and ED but with a low occurrence (Table 2). Along with termites many different organisms were also found below all the baits, such as pseudo scorpions $(n=66)$, centipedes $(n=23)$, Coleoptera $(n=16)$, as well as ants $(\mathrm{n}=3)$, millipedes $(\mathrm{n}=2)$ and snails $(\mathrm{n}=2)$.

\section{Bait preferences and soil sheeting production}

The bait consumption rates highlighted a clear preference for ED and to a lesser extent for leaves (no significant difference between $\mathrm{AC}$ and $\mathrm{LL}, \mathrm{p}=0.219$ ),

Table 1. Diversity indices (taxon richness $\mathrm{R}$ and Shannon index H') of the soil macrofauna for each treatment (elephant dung $=\mathrm{ED}$, Acacia auriculiformis leaves $=\mathrm{AC}$, Lantana camara twigs $=\mathrm{LT}$ and leaves $=\mathrm{LL}$, and wood stakes of Ficus religiosa $=$ FI, Pterocarpus marsupium $=$ PT, Prosopis juliflora $=$ PJ, Michelia champaca $=$ MI, Azadirachta indica $=$ AZ and Hevea brasiliensis $=$ HB). Values in parenthesis are standard deviations $(n=5)$.

\begin{tabular}{ccccccccccccccc}
\hline \multirow{2}{*}{ Treatments } & Control & ED & AC & LL & LT & FI & PT & PJ & MI & AZ & HB \\
\hline \multirow{2}{*}{$\mathrm{R}$} & 0.40 & 1.20 & 1.60 & 1.60 & 1.20 & 0.80 & 0.60 & 0.60 & 0.60 & 0.60 & 0.60 \\
& $(0.55)$ & $(0.84)$ & $(1.14)$ & $(0.55)$ & $(0.84)$ & $(0.84)$ & $(0.55)$ & $(0.89)$ & $(0.89)$ & $(0.55)$ & $(0.89)$ \\
\hline \multirow{2}{*}{$\mathrm{H}^{\prime}$} & 0.00 & 0.27 & 0.36 & 0.28 & 0.21 & 0.14 & 0.00 & 0.14 & 0.14 & 0.00 & 0.14 \\
& $(0.00)$ & $(0.37)$ & $(0.39)$ & $(0.27)$ & $(0.30)$ & $(0.31)$ & $(0.00)$ & $(0.31)$ & $(0.31)$ & $(0.00)$ & $(0.31)$ \\
\hline
\end{tabular}


Table 2. Soil macrofauna (total number of individuals or occurrence for termites and ants) found on the soil surface and below the baits at the end of the experiment. Baits were elephant dung ('ED'), Acacia auriculiformis leaves ('AC'), Lantana camara twigs ('LT') and leaves ('LL'), and wood stakes of Ficus religiosa ('FI'), Pterocarpus marsupium ('PT'), Prosopis juliflora ('PJ'), Michelia champaca ('MI'), Azadirachta indica ('AZ') and Hevea brasiliensis ('HB') and in the surrounding soil without bait (CTRL). Taxon meanings: Isoptera (sp.1 = Odontotermes obesus; sp. 2 = O. feae; sp. $3=$ Microtermes obesi). Coleoptera ( $\mathrm{sp} 1=$ Platypodidae $\mathrm{sp} . ; \mathrm{sp} .2$ = Bostrychidae $\mathrm{sp} . ; \mathrm{sp} .3=$ Cerambycidae sp.). Hymenoptera (sp.1 = Camponotus pennsylvanicus; sp. 2 = Monomorium minimum). Diplopoda (sp. $1=$ Millipedes). Chilopoda $(\mathrm{sp} .1$ = Centipedes). Arachinida (sp.1 = Cheliferoidea $\mathrm{sp}$.$) . Mollusca (\mathrm{sp} .1=$ snail).

\begin{tabular}{|c|c|c|c|c|c|c|c|c|c|c|c|c|}
\hline \multirow[b]{3}{*}{ Bait types } & \multicolumn{12}{|c|}{ Number of individuals or occurrence of soil macrofauna } \\
\hline & \multicolumn{3}{|c|}{ Isoptera } & \multicolumn{3}{|c|}{ Coleoptera } & \multicolumn{2}{|c|}{ Hymenoptera } & \multirow{2}{*}{$\begin{array}{c}\text { Diplopoda } \\
s p .1\end{array}$} & \multirow{2}{*}{$\begin{array}{c}\text { Chilopoda } \\
s p .1\end{array}$} & \multirow{2}{*}{$\begin{array}{c}\text { Arachinida } \\
s p .1\end{array}$} & \multirow{2}{*}{$\begin{array}{c}\text { Mollusca } \\
s p .1\end{array}$} \\
\hline & sp.1 & sp.2 2 & sp.3 & sp.1 & sp.2 & sp.3 & sp. 1 & sp.2 & & & & \\
\hline $\mathrm{AC}$ & 1 & 1 & & & & 2 & & & & 2 & 14 & \\
\hline LT & & & & & & & & 1 & 1 & 3 & 9 & \\
\hline PT & & & & & & & & & & 2 & & \\
\hline PJ & & & & & 2 & & & & & 1 & 1 & \\
\hline MI & & & & & & 1 & & & & 1 & & \\
\hline $\mathrm{AZ}$ & & & & & & 1 & & & & 2 & & \\
\hline
\end{tabular}

that were consumed at a rate of $98.8 \%$ and $58 \%$, respectively (ANOVA, $F_{9,40}=23.34, \mathrm{p}<0.001$ ) (Figure 1). Conversely, the amounts of bait consumed were very low for the different wood substrates (no significant difference between FI, PT, PJ, MI, AZ and HB, $\mathrm{p}>0.05$ ). The consumption rates of LT were

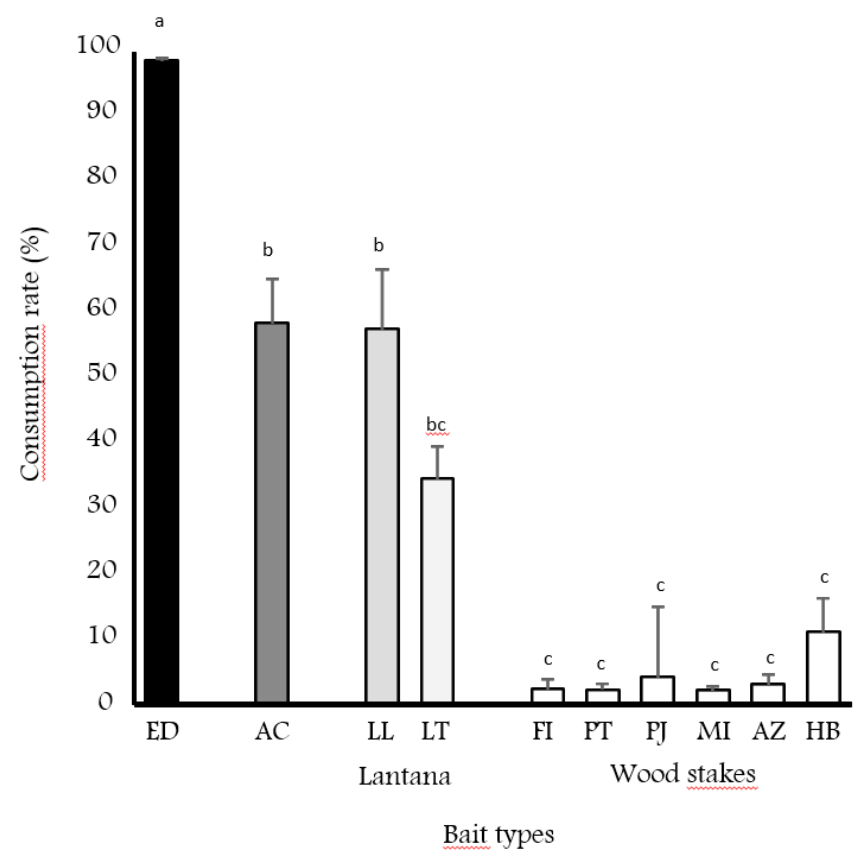

Figure 1. Baits preference and consumption by soil macrofauna, in $\%$ weight loss of the initial bait materials (elephant dung ('ED'), Acacia auriculiformis leaves ('AC'), Lantana camara twigs ('LT') and leaves ('LL'), wood stakes of Ficus religiosa ('FI'), Pterocarpus marsupium ('PT'), Prosopis juliflora ('PJ'), Michelia champaca ('MI'), Azadirachta indica ('AZ') and Hevea brasiliensis ('HB')). Vertical bars are standard errors. Histograms with the same letter are not significantly different at $\mathrm{p}=0.05(\mathrm{n}=5)$. intermediate between those of LL and AC on one side and those for the wood substrates on the other side ( $p<0.05$ in all cases).

The quantity of soil sheetings also varied between substrates (Kruskal-Wallis Chi Squared $=34.33$, $\mathrm{df}=9, \mathrm{p}<0.001$; Figure 2). ED, LT and LL were covered with $2.18 \mathrm{~g}$ soil $\mathrm{g}$ bait $^{-1}$, while the wood substrates were covered with only $0.09 \mathrm{~g}$ soil $\mathrm{g}$ bait $^{-1}$. Intermediate values were measured for AC with $0.9 \mathrm{~g}$ soil $\mathrm{g} \mathrm{bait}^{-1}(\mathrm{p}>0.05$ in all cases, except with ED where $\mathrm{p}=0.041)$. A positive relationship was found between the total amount of soil sheetings (in grams) and the bait consumption rate (in \%) $\left(y=9.69 x ; R^{2}=0.75 ; p<0.001 ;\right.$ Figure 3$)$.

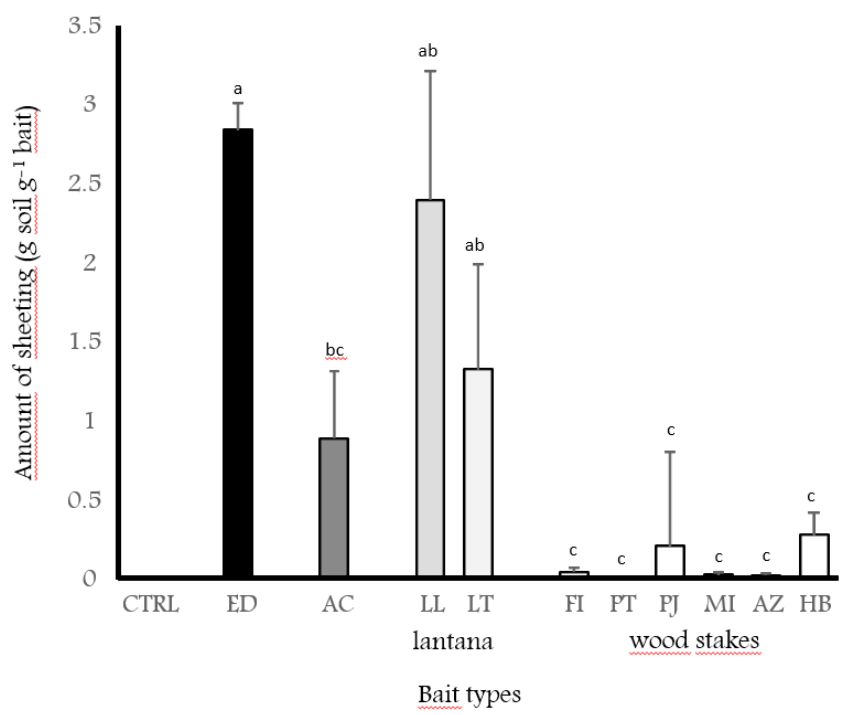

Figure 2. Amount of soil sheetings (in grams) produced by termites on the different bait types (see legend of Figure 1 for more details concerning the treatments). Vertical bars are standard errors. Histograms with the same letter are not significantly different at $\mathrm{p}=0.05(\mathrm{n}=5)$. 


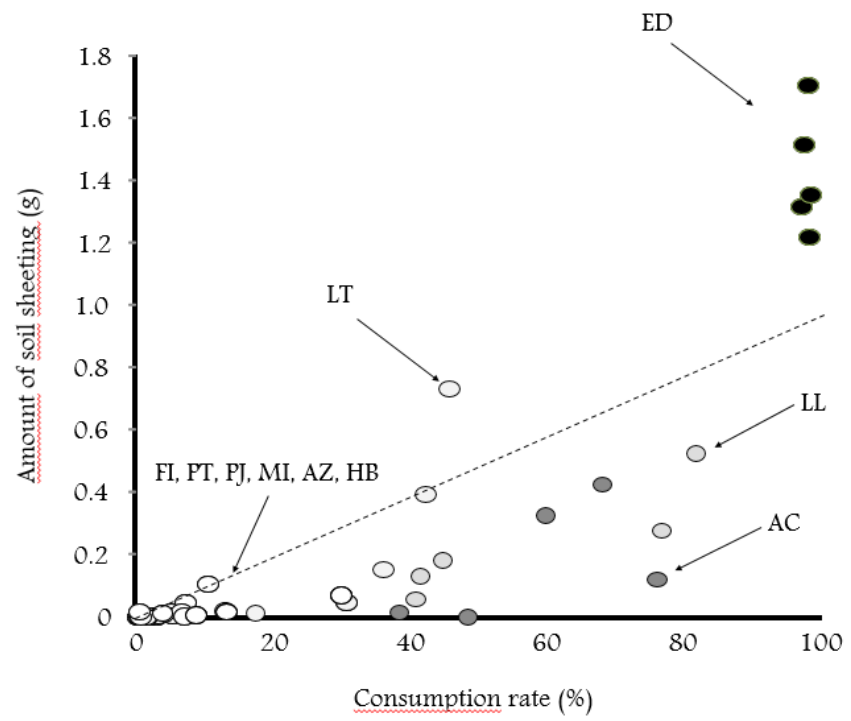

Figure 3. Relationship between termite feeding preference (in \% bait consumption) and the amount of soil translocated (in grams). See legend of Figure 1 for more details concerning the treatments. The dashed line corresponds to the linear regression.

\section{Soil belowground properties}

Termite activity did not have a significant effect on soil bulk density $\left(0.93 \mathrm{~g} \mathrm{~cm}^{-3}\right.$ in average; ANOVA test, $F_{10,44}=$ $1.47, \mathrm{p}=0.183)$ or soil moisture at saturation $\left(F_{10,44}=0.79, \mathrm{p}=\right.$ 0.637). However, water infiltration below the baits during the three first consecutive trials showed significant differences between treatments $\left(F_{10,43}=6.54, \mathrm{p}<0.001\right.$, Figure 4$)$. The highest infiltration rate was measured for ED with an infiltration rate of $26.8 \mathrm{~mL} \mathrm{sec}{ }^{-1}(\mathrm{p}<0.05$ in all cases). No difference occurred between the other substrates with an average water infiltration rate of $4.5 \mathrm{~mL} \mathrm{sec} \mathrm{s}^{-1}(\mathrm{p}>0.05$ in all cases), except for $\mathrm{AC}$ with intermediate average values of

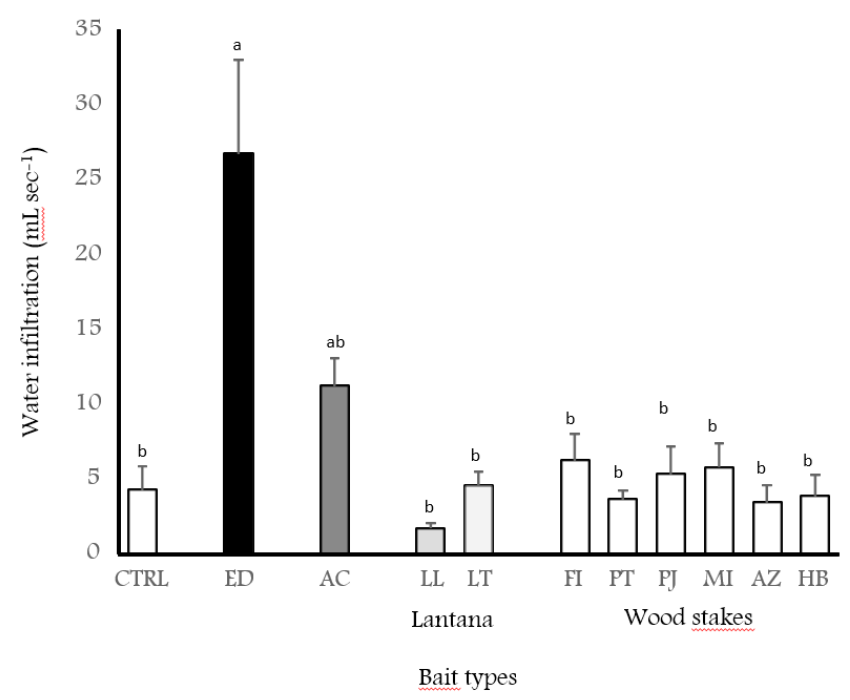

Figure 4. Water infiltration rates of the soil below of the baits $(\mathrm{mL}$ water $\left.\mathrm{sec}^{-1}\right)$ at the beginning of the Beerkan experiment. Vertical bars are standard errors. Histograms with the same letter are not significantly different at $P=0.05(\mathrm{n}=5)$. See legend of Figure 1 for more details concerning the treatments.
$11.3 \mathrm{~mL} \mathrm{sec}^{-1}$. Figures $5 \mathrm{a}, \mathrm{b}$ show that the infiltration rate at the beginning of the experiment was linearly related to the consumption rate and the amount of soil sheetings $(\mathrm{y}=$ $0.18 \mathrm{x}+3.02, \mathrm{R}^{2}=0.46, \mathrm{p}<0.001 ; \mathrm{y}=0.01 \mathrm{x}+4.52, \mathrm{R}^{2}=$ $0.55, \mathrm{p}<0.001$, for the consumption rate and the quantity of soil sheeting, respectively). However, the baits did not significantly influence the steady state infiltration rate $(\sim 0.96$ $\mathrm{mL} \mathrm{sec}{ }^{-1}$ on average; Kruskal-Wallis Chi-squared test $=8.76$, $\mathrm{df}=10, \mathrm{p}=0.555$ ).

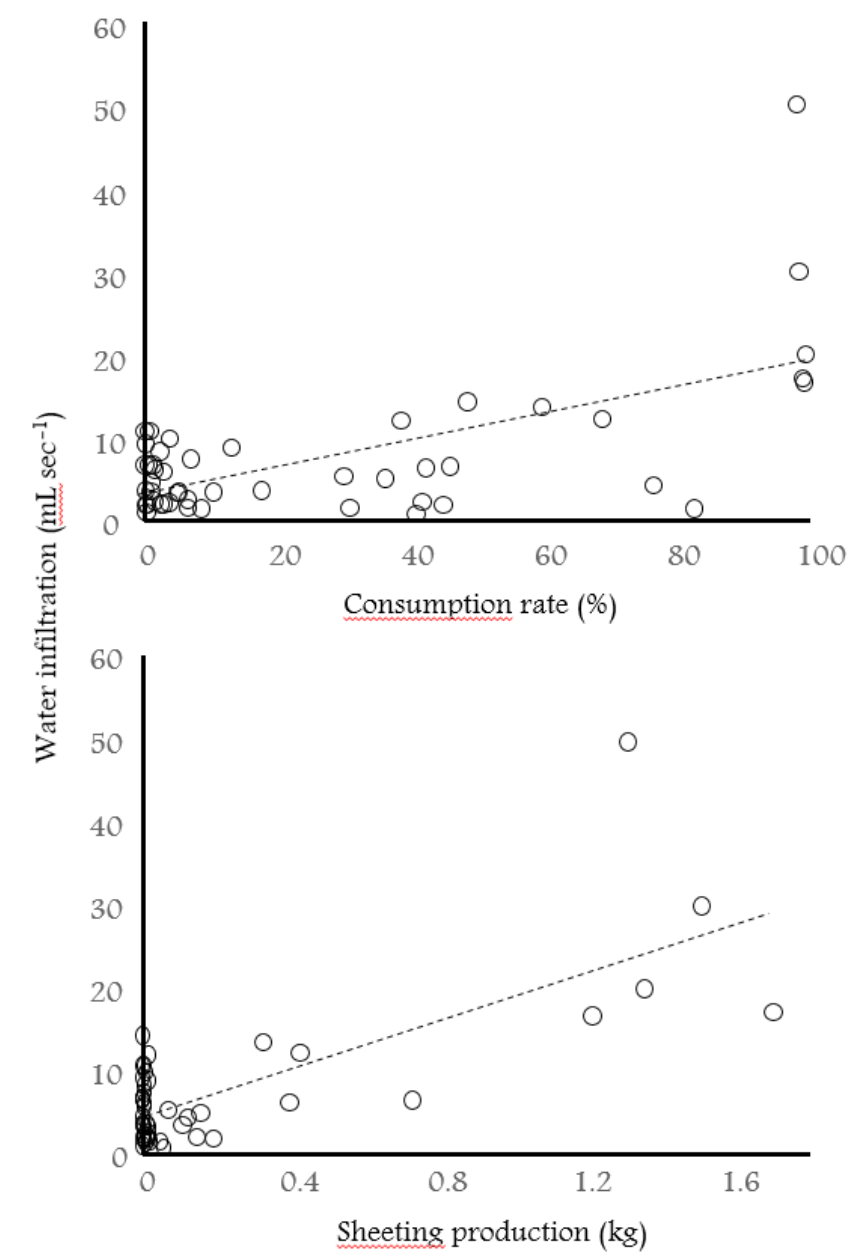

Figure 5a, b. Relationships between water infiltration rate of the soil below of the baits at the beginning of the Beerkan experiment (in $\mathrm{mm} \mathrm{sec}$ ) and soil macrofauna feeding preference (in \% bait consumption) or the amount of soil sheetings (in $\mathrm{kg}$ soil). Linear regressions are displayed.

\section{Discussion}

\section{Impact of the baits on soil biodiversity}

In total, three termite species were identified (Table 2). Along with termites, several soil macrofauna were observed below the baits. Some could be associated with litter degradation (e.g., snails, millipedes) while others were predators (e.g., ants, chilopods). Unfortunately, due to the overall low number of soil macrofauna individuals and number of repetition $(n=5)$ we could not determine if some of the baits were more attractive than others (i.e. no significant 
difference in $\mathrm{R}$ and $\left.\mathrm{H}^{\prime}\right)$. In addition, termites were not sampled with most the baits, although the presence of sheetings showed that ED, AC, LL and LT baits were attractive to them. Since samples were collected only once after a period of six months, it is also possible that other termite species and/or other soil invertebrates were also involved in earlier decomposition stages of the baits but were no longer active when samples were collected (Sundararaj et al., 2015). Similarly, six months is a short period for wood decomposition (van Geffen et al., 2010) and it is also possible that other termite species would have been found associated with wood baits if the experiment had lasted longer.

\section{Termite feeding preference and soil translocation}

Termites produce sheetings mainly to protect themselves from direct sunlight and predation while they forage (Jouquet et al., 2006, 2015; Harit et al., 2017b), and to excavate soil to construct below-ground galleries and nest chambers (Harit et al., 2017a). Termites do not always cover the food material on which they feed with sheetings but in this study a clear relationship was measured between the amount of sheetings produced over the feeding substrate and the amount of substrate that was consumed. This result therefore confirms the study of Rouland et al. (2003) who found a positive relationship between the amount of millet cane consumed by termites and the quantity of soil sheetings. It is also in agreement with Jouquet et al. (2015) and Harit et al. (2017a) who showed that when termites prefer a food they invest more energy in the production of soil sheetings.

Soil translocation levels were the highest for ED samples since all the elephant dung was covered and filled in with sheetings. Termites clearly preferred ED over the other baits, most likely because of its high $\mathrm{C}$ and $\mathrm{N}$ contents ( $\sim 0$ and $1 \%$ in South Indian woodlands, respectively; Chaudhary com. pers.) (Freymann et al., 2008). ED was also perhaps more attractive to termites because it is a mechanically and biochemically "preprocessed" substrate, after its passage through the elephant gut. Indeed, it is likely that its high mass per volume ratio in comparison reduced the energy needed for termites, and their symbiotic fungi, to mechanically and biochemically break it down (He, 2013). Termites then preferred feeding on leaves and to a lesser extent twigs but wooden baits were almost left untouched by termites during this experiment. This preference can easily be explained by the fact that leaves are less dense and enriched in $\mathrm{N}$ compared with twigs and wood (e.g. 2.4\% and $0.62 \%$ of $\mathrm{N}$ in leaves and wood of Acacia, respectively; Snowdon et al., 2005). Due to the low consumption of wood we could not confirm the results of Shanbhag and Sundararaj (2013a, b) who showed that Odontotermes spp. termites prefer less dense wood over denser wood types. Finally, this study also showed that termites can consume Lantana camara, which is an invasive species in India where it is becoming a threat to biodiversity (Priyanka \& Joshi, 2013). Therefore, this study confirms the key role played by termites in the decomposition of litter and herbivore dung in tropical ecosystems (Collins, 1981; Freymann et al., 2008). It also suggests that L. camara is likely to be degraded by termites in South Indian forests, despite the fact that it contains secondary metabolites that are used for biological control of forest pests, including termites (Verma et al., 2009; Yuan \& Hu, 2012).

\section{Effects of termites on water infiltration}

In our experiment, the consumption rate and amount of soil sheetings were linearly related to the water infiltration rate at the beginning of the Beerkan measurements. It is likely that the higher water infiltration in soil for the ED treatment resulted from the higher foraging activity of termites below ED. Hence a larger number and/or diameter of galleries may have been produced in the area, as shown by the greater excavation of soil in the form of sheetings. Our study confirmed the higher water infiltration rate associated with termite foraging activity (Mando \& Miedema, 1997; Léonard \& Rajot, 2001; Léonard et al., 2004; Kaiser et al., 2017). However, this higher water infiltration rate was only significant for the initial stages of the experiment and no significant differences were found in the later stages. Consequently, this result suggests that the macropores produced by termites were unstable. It is likely that galleries were initially playing the role of preferential flow paths, improving water infiltration in the soil, but that they did not resist the successive applications of water on the soil and collapsed, leading to similar soil porosity for all the treatments. This scenario would explain why no difference in soil bulk density and soil humidity at saturation was measured at the end of the experiment. It also suggests that termite foraging activity has a rather limited impact on soil porosity after prolonged rains. These conclusions are, however, in contradiction with results found in Africa where fungusgrowing termites increased soil porosity and water infiltration and retention (Mando \& Miedema, 1997; Konaté et al., 1999; Léonard \& Rajot, 2001; Léonard et al., 2004; Kaiser et al., 2017). Different soil properties between our study site and the study sites in Africa could explain these differences. In Africa, soils were mainly sandy with a high bulk density ( $>$ 1.5-2), while in our study site the soil was characterized by a very low bulk density ( $\sim 0.9$, Shanbhag, pers. obs.) and a good water drainage, which is a characteristic of Luvisol (Soil Survey Staff, 2014). More research is therefore clearly needed to examine how the impact of termites, and especially the stability of their foraging galleries, vary with soil properties.

\section{Conclusion}

The aim of this study was to gain a better understanding of the relationship between termite food preferences and the ecological benefits derived from their activity in terms of soil dynamics and water infiltration. A clear relationship was found between termite feeding preference, soil sheeting 
production and water infiltration, at least in the initial stages of the experiment. Thus, this confirms the need for new data concerning the link between plot-scale termite ecology and their impacts on ecosystem processes. The lack of evidence in the present study that termites affect water infiltration raises questions about the stability of termite foraging galleries and their overall role in regulating soil bulk density in Luvisol. Therefore, a perspective of this study would be to test the generality of this result in other soil pedological contexts (e.g., in compacted or poorly draining soils). Finally, another key conclusion of this study is the ability of termites to consume Lantana camara residues, which cannot be eaten by most other forest insects in India.

\section{Acknowledgements}

Authors are gratefully acknowledging the financial support provided by University Grant Commission, India (Grant No. No. F.15-1/2014-15/PDFWM-2014-15-GE-KAR-22426 (SA-II) dated 30-Jan-2015). We also thank the Editor and the two anonymous reviewers for their useful suggestions on the draft script. This research was funded by the Indo-French Cell for Water Science (LMI IFCWS/CEFIRSE, IRD) and the French National Program EC2CO-Biohefect "MACROFLUX".

\section{References}

Ali, I.G., Sheridan, G., French, J.R.J. \& Ahmed, B.M. (2013). Ecological Benefits of Termite Soil Interaction and Microbial Symbiosis in the Soil Ecosystem. Journal of Earth Sciences and Geotechnical Engineering 3: 63-85.

Bignell, D.E. (2006). Termites as soil engineers and soil processors. In Intestinal microorganisms of termites and other invertebrates. Springer Berlin Heidelberg. pp 183-220.

Bottinelli, N., Jouquet, P., Capowiez, Y., Podwojewski, P., Grimaldi, M. \& Peng, X. (2015). Why is the influence of soil macrofauna on soil structure only considered by soil ecologists? Soil Tillage Research. 146: 118-124. doi: 10.1016/j.still.2014.01.007

Braud, I., De Condappa, D., Soria, J. M., Haverkamp, R., Angulo-Jaramillo, R., Galle, S. \& Vauclin, M. (2005). Use of scaled forms of the infiltration equation for the estimation of unsaturated soil hydraulic properties (the Beerkan method). European Journal of Soil Science, 56: 361-374. doi: 10.11 11/j.1365-2389.2004.00660.x

Cheik, S., Bottinelli, N., Sukumar R. \& Jouquet, P. (2018) Fungus-growing termite foraging activity increases water infiltration but only slightly impacts soil physical properties in Southern Indian woodlands. European Journal of Soil Biology 89: 20-24. doi: 10.1016/j.ejsobi.2018.09.001

Collins, N.M. (1981). The role of termites in the decomposition of wood and leaf litter in the southern Guinea savanna of Nigeria. Oecologia, 51: 389-399. doi: 10.1007/BF00540911
Dangerfield, J.M., McCarthy, T.S. \& Ellery, W.N. (1998). The mound-building termite Macrotermes michaelseni as an ecosystem engineer. Journal of Tropical Ecology, 14: 507- 520.

Elkins, N.Z., Sabol, G.Z., Ward, T.J. \& Whitford, W.G. (1986). The influence of subterranean termites on the hydrological characteristics of a Chihuahuan desert ecosystem. Oecologia, 68(4): 521-528. doi: 10.1007/BF00378766

Evans, T. A., Dawes, T. Z., Ward, P. R., \& Lo, N. (2011). Ants and termites increase crop yield in a dry climate. Nature communications, 2, 262. doi: 10.1038/ncomms 1257

Fatondji, D., Martius, C., Bielders, C.L., Koala, S., Vlek, P.L.G. \& Zougmore, R. (2009). Decomposition of organic amendment and nutrient release under the Zai technique in the Sahel. Nutrient Cycling in Agroecosystem, 85: 225-239. doi: 10.1007/s10705-009-9261-z

Freymann, B.P., Buitenwerf, R., Desouza, O. \& Olff, H. (2008). The importance of termites (Isoptera) for the recycling of herbivore dung in tropical ecosystems: a review. European Journal of Entomology, 105: 65-173. doi: 10.14411/eje.2008.025

Freymann, B.P., de Visser, S.N. \& Olff, H. (2010). Spatial and temporal hotspots of termite driven decomposition in the Serengeti. Ecography, 33: 443-450. doi: 10.1111/j.16000587.2009.05960.x.

Harit, A., Moger, H., Duprey, J.L., Gajalakshmi, S., Abbasi, S.A., Subramanian, S. \& Jouquet, P. (2017a). Termites can have greater influence on soil properties through the construction of soil sheetings than the production of aboveground mounds. Insectes Sociaux, 64: 247-253. doi: 10.1007/ s00040-017-0541-3

Harit, A., Shanbhag, R.R., Chaudhary, E., Cheik, S. \& Jouquet, P. (2017b). Properties and functional impact of termite sheetings. Biology and Fertility of Soils, 53: 743-749. doi: 10.1007/s00374-017-1228-7

Harry, M., Jusseaume, N., Gambier, B. \& Garnier-Sillam, E. (2001). Use of RAPD markers for the study of microbial community similarity from termite mounds and tropical soils. Soil Biology and Biochemistry, 33(4-5): 417-427. doi: 10.10 16/S0038-0717(00)00181-4

Haverkamp, R., Ross, P.J., Smettem, K.R.J. \& Parlange, J.Y. (1994). Three-dimensional analysis of infiltration from the disc infiltrometer: 2. Physically based infiltration equation. Water Resources Research, 30: 2931-2935. doi: 10.1029/94WR01788

He, S. (2013). Comparative Metagenomic and Metatranscriptomic Analysis of hindgut Paunch Microbiota in Wood and dung Feeding Higher Termite. Plos One 8 (4), E61126. doi: 10.1371/ journal.pone.0061126

Herrick, J.E. \& Lal, R. (1996). Dung decomposition and pedoturbation in a seasonally dry tropical pasture. Biology and Fertility of Soils, 23: 177-181. doi: 10.1007/BF00336060 
Holt, J. A. \& Lepage, M. (2000). Termites and soil properties. In Abe, T.; Bignell, D. E., Higashi, M. (eds.). Termites: Evolution, Sociality, Symbiosis, Ecology. Kluwer Academic Publishers, Dordrecht, 389-407. doi: 10.1007/978-94-017-3223-9_18

Horiuchi, Y., Ohno, T., Hoshino, M., Shin, K.C., Murakami, H., Tsunematsu, M. \& Watanabe, Y. (2014). Geochemical prospecting for rare earth elements using termite mound materials. Mineralium Deposita 49: 1013-1023. doi: 10.1007/ s00126-014-0550-3

Jones, C.G., Lawton, J.H. \& Shachak, M. (1994). Organisms as ecosystem engineers. Oikos, 69: 373-386. doi: 10.1007/9781-4612-4018-1_14

Joseph, G.S., Seymour, C.L., Cumming, G.S., Cumming, D.H.M. \& Mahlangu, Z. (2014). Termite mounds increase functional diversity of woody plants in African savannas. Ecosystems, 17(5): 808-819. doi: 10.1007/s10021-014-9761-9.

Jouquet, P., Lepage, M. \& Velde, B. (2002). Termite soil preferences and particle selections: Strategies related to ecological requirements. Insectes Sociaux, 49(1): 1-7. doi: 10.1007/s00040-002-8269-z

Jouquet, P., Mery, T., Rouland, C. \& Lepage, M. (2003). Modulated effect of the termite Ancistrotermes cavithorax (Isoptera, Macrotermitinae) on soil properties according to the internal mound structures. Sociobiology, 42(2): 403-412.

Jouquet, P., Ranjard, L., Lepage, M. \& Lata, J. (2005). Incidence of fungus-growing termites (Isoptera, Macrotermitinae) on the structure of soil microbial communities. Soil Biology and Biochemistry, 37(10): 1852-1859. doi: 10.1016/j. soilbio.2005.02.017

Jouquet, P., Dauber, J., Lagerlof, J., Lavelle, P. \& Lepage, M. (2006). Soil invertebrates as ecosystem engineers: intended and accidental effects on soil and feedback loops. Applied Soil Ecology, 32: 153-164. doi: 10.1016/j.apsoil.2005.07.004

Jouquet, P., Traoré, S., Choosai, C., Hartmann, C. \& Bignell, D. (2011). Influence of termites on ecosystem functioning. Ecosystem services provided by termites. European Journal of Soil Biology, 47(4): 215-222. doi: 10.1016/j. ejsobi.2011.05.005

Jouquet, P., Guilleux, N., Chintakunta, S., Mendez, M. \& Shanbhag, R.R. (2015). The influence of termites on soil sheeting properties varies depending on the materials on which they feed. European Journal of Soil Biology, 69: 7478. doi: 10.1016/j.ejsobi.2015.05.007

Jouquet, P., Bottinelli, N., Shanbhag, R.R., Bourguignon, T., Traoré, S. \& Abbasi, S.A. (2016). Termites: the neglected soil engineers of tropical soils. Soil Science, 181: 157-165. doi: 10.1097/SS.0000000000000119

Jouquet, P., Airola, E., Guilleux, N., Harit, A., Chaudhary, E., Grellier, S. \& Riotte, J. (2017). Abundance and impact on soil properties of cathedral and lenticular termite mounds in Southern Indian woodlands. Ecosystems, 20: 769-780. doi: 10.1007/s10021-016-0060-5

Jouquet, P., Chaudhary, E. \& Kumar, A.R.V. (2018). Sustainable use of termite activity in agro-ecosystems with reference to earthworms. A review. Agronomy for Sustainable Development 38, 3. doi: 10.1007/s13593-017-0483-1

Kaiser, D., Lepage, M., Konaté, S. \& Linsenmair, K.E. (2017). Ecosystem services of termites (Blattoidea: Termitoidae) in the traditional soil restoration and cropping system Zaï in northern Burkina Faso (West Africa). Agriculture, Ecosystems \& Environment, 236: 198-211. doi: 10.1016/j.agee.2016.11.023

Konaté, S., Le Roux, X., Tessier, D. \& Lepage, M. (1999). Influence of large termitaria on soil characteristics, soil water regime, and tree leaf shedding pattern in a West African savanna. Plant \& Soil, 206: 47-60. doi: 10.1023/A:1004321023536

Lavelle, P., Bignell, D. \& Lepage, M. (1997). Soil function in a changing world: the role of invertebrate ecosystem engineers. European Journal of Soil Biology, 33: 159-193.

Lavelle, P., Decaëns, T., Aubert, M., Barot, S., Blouin, M., Bureau, F., Margerie, P., Mora, P. \& Rossi, J.-P. (2006). Soil invertebrates and ecosystem services. European Journal of Soil Biology, 42: 3-15. doi: 10.1016/j.ejsobi.2006.10.002

Lee, K.E. \& Wood, T.G. (1971) Physical and chemical effects on soils of some Australian termites, and their pedological significance. Pedobiologia, 11: 376-409.

Léonard, J. \& Rajot, J.L. (2001). Influence of termites on runoff and infiltration: quantification and analysis. Geoderma, 104: 17-40. doi: doi.org/10.1016/S0016-7061(01)00054-4

Léonard, J., Perrier, E. \& Rajot, J.L. (2004). Biological macropores effect on runoff and infiltration: a combined experimental and modelling approach. Agriculture, Ecosystems \& Environment, 104: 277-285. doi: 10.1016/j.agee.2003.11.015

Lobry de Bruyn, L.A. \& Conacher, A.J. (1990). The role of termites and ants in soil modification: A review. Australian Journal of Soil Research, 28: 55-93. doi: 10.1071/SR9900055

Mando, A., Stroosnijder, L. \& Brussaard, L. (1996). Effects of termites on infiltration into crusted soil. Geoderma, 74: 107-113. doi: 10.1016/S0016-7061(96)00058-4

Mando, A. \& Miedema, R. (1997). Termite-induced change in soil structure after mulching degraded (crusted) soil in the Sahel. Applied Soil Ecology, 6: 241-249. doi: 10.1016/ S0929-1393(97)00012-7

Mando, A., Brussaard, L. \& Stroosnijder, L. (1999). Termiteand mulch-mediated rehabilitation of vegetation on crusted soil in West Africa. Restoration Ecology, 7: 33-41. doi: 10.1046/j.1526-100X.1999.07104.X

Mettrop, I.S., Cammeraat, L.H. \& Verbeeten, E. (2013). The impact of subterranean termite activity on water infiltration 
and topsoil properties in Burkina Faso. Ecohydrology 6, 324331. doi: 10.1002/eco.1271

Moe, S.R., Mobaek, R. \& Narmo, A.K. (2009). Mound building termites contribute to savanna vegetation heterogeneity. Plant Ecology, 202: 31-40. doi: 10.1007/s11258-009-9575-6

Muvengwi, J., Parrini, F., Witkowski, E.T.F. \& Davies, A.B. (2018). Are Termite Mounds Always Grazing Hotspots? Grazing Variability with Mound Size, Season and Geology in an African Savanna. Ecosystems, in press. doi: 10.1007/ s10021-018-0257-x

Ouédraogo, E., Mando, A. \& Brussaard, L. (2006). Soil macrofauna affect crop nitrogen and water use efficiencies in semi-arid West Africa. European Journal of Soil Biology, 42: 275-277. doi: 10.1016/j.ejsobi.2006.07.021

Pringle, R.M., Doak, D.F., Brody, A.K., Jocqué, R. \& Palmer, T.M. (2010). Spatial pattern enhances ecosystem functioning in an African savanna. PLoS Biology 8, 1000377. doi: 10.1371/journal.pbio. 1000377

Priyanka, N. \& Joshi, P.K. (2013). A review of Lantana camara studies in India. International Journal of Scientific and Research Publications 3, 1-11.

Ramaswami, G. \& Sukumar, R. (2014). Lantana camara L. (Verbenaceae) invasion along streams in a heterogeneous landscape. Journal of Biosciences, 39, 717-726. doi: 10.1007/ s12038-014-9465-5.

R Development Core Team (2008). R: A Language and Environment for Statistical Computing. R Foundation for Statistical Computing, Vienna, Austria (accessed at bhttp:// www.R-project.orgN.).

Rouland, C., Lepage, M., Chotte, J. L., Diouf, M., Ndiaye, D., Ndiaye, S., Seuge, C. \& Brauman, A. (2003). Experimental manipulation of termites (Isoptera, Macrotermitinae) foraging patterns in a Sahelo-Sudanese savanna: effect of litter quality. Insectes Sociaux, 50: 309-316. doi: 10.1007/s00040-003-0680-6

Schaefer, D.A. \& Whitford, W.G. (1981). Nutrient cycling by the subterranean termite Gnathamitermes tubiformans in a Chihuahuan Desert ecosystem. Oecologia, 48: 277-283. doi: 10.1007/BF00347977

Shanbhag, R.R. \& Sundararaj, R. (2013a). Effect of physical and chemical properties of imported woods on the degradation by termites in Indian condition. Journal of Insect Science, 13: 63. doi: 10.1673/031.013.6301

Shanbhag, R.R. \& Sundararaj, R. (2013b). Imported wood decomposition by termites in different agro eco zones of India. International Biodeterioration \& Biodegradation, 85: 16-22. doi: 10.1016/j.ibiod.2013.03.037

Shanbhag, R.R., Sundararaj, R., Kabbaj, M. \& Jouquet, P. (2017). Rainfall and soil properties influence termite mound abundance and height. A case study with Odontotermes obesus
(Macrotermitinae) mounds in the Indian Western Ghats forests. Applied soil Ecology: 111, 33-38. doi: 10.1016/j. apsoil.2016.11.011

Sileshi, G.W., Arshad, M.A., Konaté, S. \& Nkunika, P.O.Y. (2010). Termite-induced heterogeneity in African savanna vegetation: mechanisms and patterns. Journal of Vegetation Science, 21: 923-937. doi: 10.1111/j.1654-1103.2010.01197.x

Snowdon, P., Ryan, P. \& Raison, J. (2005). Review of C:N ratios in vegetation, litter and soil under Australian native forests and plantations. National Carbon Accounting System Technical Report No. 45. Australian Greenhouse Office.

Sousa, E.O. \& Costa, J.G.M. (2012). Genus Lantana: chemical aspects and biological activities. Brazilian Journal of Pharmacognosy, 22: 1155-1180. doi: 10.1590/S0102-695 X2012005000058

Soil Survey Staff (2014). Keys to Soil Taxonomy, 12th ed. USDANatural Resources Conservation Service, Washington, DC.

Sujada, N., Sungthong, R. \& Lumyong, S. (2014). Termite Nests as an Abundant Source of Cultivable Actinobacteria for Biotechnological Purposes. Microbes and Environments 29: 211-219. doi : 10.1264/jsme2.ME13183

Sundararaj, R., Shanbhag, R.R., Nagaveni, H.C. \& Vijayalakshmi, G. (2015). Natural Durability of Timbers under Indian environmental condition. An overview. International Biodeterioration \& Biodegradation, 103: 196214. doi: 10.1016/j.ibiod.2015.04.026

Turner, J.S. (2004). Extended phenotypes and extended organisms. Biology and Philosophy 19, 327-352. doi: 10.1023/B:BIPH.0000036115.65522.a1

van Geffen, K.G., Poorter, L. , Sass-Klaassen, U., van Logtestijn, R.S. \& Cornelissen, J.H. (2010). The trait contribution to wood decomposition rates of 15 Neotropical tree species. Ecology, 91: 3686-3697. doi:10.1890/09-2224.1

Verma, M., Sharma, S. \& Prasad, R. (2009). Biological alternatives for termite control: A review. International Biodeterioration \& Biodegradation, 63: 959-972. doi: 10.1016/j.ibiod.2009.05.009

Wood, T.G. \& Sands, W.A. (1978). The Role of Termites in Ecosystems. In Production Ecology of Ants and Termites; Brian, M.V., Ed.; Cambridge University Press: Cambridge, UK, 245-292.

Yuan, Z. \& Hu, X.P. (2012). Repellent, antifeedant, and toxic activities of Lantana camara leaf extract against Reticulitermes flavipes (Isoptera: Rhinotermitidae). Journal of Economic Entomology, 105: 2115-2121. doi: 10.1603/EC12026

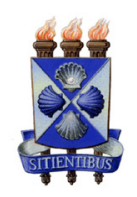

